\title{
Self-Appreciation; or, The Aspirations of Human Capital
}

\author{
Michel Feher
}

\begin{abstract}
Whether they call on the Left to modernize its project or to return to its values, advocates of a renewed progressive agenda at least agree on the need to break down the hegemony of neoliberalism. With this as their objective, the "modernizers" recommend what ultimately amounts to the administration of pain reducers: they want measures that would lessen the social effects of neoliberal policies, along with regulations that would spare some institutions from the influence of neoliberal management. Supporters of an "authentic" Left, meanwhile, call instead for a frontal opposition to neoliberalism, advocating an unapologetic program of wealth redistribution, greater security for salaried workers, and broader public services. These are in many ways opposite strategies, of course, but in both cases neoliberalism is approached from without - whether to limit its negative effects and contain its ambitions or to oppose it with an antagonistic logic. My own objective in the following pages, by contrast, is to explore the possibility of defying neoliberalism from within - that is, by embracing the very condition that its discourses and practices delineate.

Such an approach is informed both by Michel Foucault's reflections on the early days of feminism and by Karl Marx's analysis of the "free laborer." Consider Foucault first:
\end{abstract}

For a long time they tried to pin women to their sex. For centuries they were told: "You are nothing but your sex." And this sex, doctors added, is fragile, almost always sick and always inducing illness. . . . But the feminist movements responded defiantly. Are we sex by nature? Well then, let us be so but in its singularity, in its irreducible specificity. Let us draw the

An earlier version of this article appeared in Raisons politiques, no. 28 (2007).

Public Culture 21:1 Dol 10.1215/08992363-2008-019 
consequences and reinvent our own type of existence, political, economic and cultural. ${ }^{1}$

Instead of rejecting sexual norms that were meant to colonize and subject women, Foucault claims, early feminists endeavored to work through them, that is, to embrace them but only to impart them with unexpected meanings and to put them to unforeseen uses.

Now, take Marx: liberal capitalism, the author of Capital tells us, is inseparable from the notion of the "free laborer." Behind this label, however, what one really sees is a worker whose freedom amounts to dispossession. Indeed, the free worker has been robbed of everything: the capacity to choose his or her occupation, the ownership of the means of production, and the product of his or her activity. This is the lot of the salaried worker, whose labor power is rented out to an employer - who in turn decides on the use of this labor power and owns both the tools of production and the product itself. As Marx also points out, however, bourgeois law establishes an equivalence, a formal equality between the salaried worker and the employer: both are understood as subjects who are free to dispose of their property (be it labor power or capital) and to exchange it at its proper value in the marketplace. ${ }^{2}$ Does this mean that the role of the labor movement is to denounce the fiction of the free laborer and call on workers to refuse it as an ideological deception? While it is certainly part of the Marxist heritage (for better and for worse) to expose the "formal" equality offered by liberal democracies as a condition of reproduction of the "real" inequalities created by capitalism, it is also the case that the labor movement (including in its Marxist variant) has organized along rather different lines: labor unions have indeed relied on this very notion of the free laborer, and the labor movement even developed as a movement of free laborers whose union and solidarity were meant either to maximize the exchange value of their labor power or, in a more radical vein, to precipitate the crisis of capitalism - since the infamous tendency of the rate of profit to fall (due to the mechanization of industry) means that capitalists always need to increase the exploitation of labor power.

In short, one can hear in both Marx and Foucault a call to accept and inhabit a certain mode of subjection in order to redirect it or turn it against its instigators.

1. Michel Foucault, "Power and Sex," in Politics, Philosophy, Culture: Interviews and Other Writings, 1977-1984, ed. Lawrence D. Kritzman, trans. Alan Sheridan et al. (New York: Routledge, 1988), $115-16$.

2. Karl Marx, "The Sale and Purchase of Labour-Power," chap. 6 of A Critique of Political Economy, vol. 1 of Capital, trans. Ben Fowkes (New York: Vintage, 1977). 
The question remains, however, of knowing who is the subject of neoliberalism or, more precisely, of knowing what type of subjectivity is being simultaneously presupposed and targeted by neoliberal policies. On this question, Marx and Foucault once again offer invaluable lessons: Marx, first, because the relation between the neoliberal condition (which I shall try to define) and the condition of the free laborer may be understood in terms of homology and genealogy (i.e., the neoliberal condition is to neoliberalism as the condition of the free laborer is to liberal capitalism). Foucault, too, is helpful, because he chose neoliberalism as the topic of his lectures at the Collège de France in 1979 — at the precise time when this economic theory was becoming the new orthodoxy (Margaret Thatcher became prime minister in May 1979, and in July of the same year Paul Volcker, the architect of the monetarist revolution, became chairman of the Federal Reserve). ${ }^{3}$

To define the traits of the neoliberal condition, let us first return to the free laborer analyzed by Marx. As Marx has shown us, insofar as it treats us as subjects who are free to dispose of what resources we own (be it capital or labor power), liberalism can legitimately claim to be a humanism, for it never confuses what we are with what we own and therefore never treats us as commodities that can be appropriated. We are sovereign subjects, free to dispose of what we own, and this grants us inalienable rights (such as the right not to be taken for commodities and the right to bargain over what we own and thus sell it at the best possible price). At the same time, this also leaves us with needs and aspirations that cannot be reduced to interests (which could be satisfied according to the law of supply and demand). In other words, liberal capitalism recognizes and even presupposes that we do not grow spiritually rich in the same way that we acquire material wealth. The difference between the two kinds of growth is an essential feature of the liberal condition insofar as the latter predicates the reproduction of subjects who will make good use of their natural propensity to optimize their interests on various forms of nurturing through which disinterested care is both provided as emotional nourishment and morally valued as a necessary complement to profitable endeavors.

Indeed, from a liberal perspective, love, religion, and culture cannot be reduced to a mere calculus of interests: they delineate an existential realm where human desires are not optimally managed through bargaining and the interplay of selfinterested exchanges but are either met or humbled by the manifestation of disin-

3. See David Harvey, A Brief History of Neoliberalism (Oxford: Oxford University Press, 2005), 1. 
terested feelings — such as divine charity, parental and spousal devotion, social and national solidarity, love and compassion for humanity, and so on. Such a realm is not only meant to complement that of the market, that is, to supplement what market relations can deliver; more than just a safety net, it is required for the formation of subjects who can distinguish between the negotiable and the inalienable and may expect to be treated according to this distinction. For it is only when the demarcation between the negotiating subject and the negotiated commodity is clearly established and enforced that the free laborer can safely submit to the laws of the market without losing his or her sense of (moral) dignity and (political) sovereignty.

As early as the second half of the nineteenth century, socialist movements largely adopted the Marxist critique of the notion of the free laborer, according to which free laborers are alienated in two senses: they are alienated insofar as they do not have control over their life (i.e., they are denied the ability to choose their activity, while both the means of production and the outcome of their labor belong to others), but they are also alienated insofar as liberal law and ideology rob them of the consciousness of their exploitation (since they are invited to consider themselves as owners of their labor power and thus as subjects endowed with a freedom that is equivalent to that of their employer). However, as mentioned above, socialists did not merely recognize and expose the fictitious and ideological character of the freedom granted to the free worker: they also seized on this construct, both in an effort to bolster the price of labor power (through the work of labor unions) and to criticize working conditions (for violating the essential distinction between man and commodity, between the laborer in his or her inalienable dignity and the labor power that he or she owns and rents out).

This dual way of appropriating the figure of the free worker has allowed the labor movement to achieve considerable victories, compounded in the advent and development of the welfare state in its various dimensions. However, in the past three decades, claims based on class interests (e.g., demands for better wages and better job security) or humanist appeals (e.g., "we are not commodities") have become less and less successful. Though this evolution, which is distinctive of the neoliberal era, can be read in terms of the crisis of the Fordist socioeconomic compact and its impact on the bargaining power of labor vis-à-vis capital, my contention is that it also reflects the decline of the type of free laborer and its gradual replacement by a new form of subjectivity: human capital. Indeed, as I shall argue, the rise of human capital as a dominant subjective form is a defining feature of neoliberalism.

To envision human capital as a subjective form or formation implies that it 
must be compared to the figure of the free laborer, rather than to the notion of labor power. In other words, my claim is that the widespread use of the concept of human capital is less a symptom of the gradual "commodification" of the liberal subject than it is the expression of an emergent neoliberal condition, the novelty of which has been so far underestimated. ${ }^{4}$ But as I shall also argue, critics of neoliberalism should not simply analyze and criticize the notion of human capital as the successor to the notion of the free laborer: instead, they ought to adopt the notion of human capital, or, to put it more bluntly, they ought to embrace the neoliberal condition, much as the workers' movement adopted the figure of the free worker, and allow it to express aspirations and demands that its neoliberal promoters had neither intended nor foreseen.

The notion of human capital, initially, did not seem all that ambitious. It referred to the set of skills that an individual can acquire thanks to investments in his or her education or training, and its primary purpose was to measure the rates of return that investments in education produce or, to put it simply, the impact on future incomes that can be expected from schooling and other forms of training. The economists who developed the concept of human capital purported to help governments devise their education policy as well as to make sense of how individuals decide whether to look for employment or to seek more training — whether it is better for them to settle for some income now or to wait and aim for a higher income later. However, thanks to the efforts of its chief promoters, Theodor W. Schultz and especially Gary S. Becker, the notion of human capital rapidly developed beyond the field of economics of education, and its heuristic ambitions soon expanded considerably.

4. While the history, structure, and modes of exploitation specific to neoliberalism have been well documented by now (be this the decline of Fordism and the corollary crisis of trade unions, the subjection of industrial to financial capital and the increasing control of corporate governance by shareholders, or the deregulation of markets and the privatization of public goods and services), the type of subject that is both constituted by this regime and tasked with upholding it has been rather less studied. To a large extent, neoliberalism's detractors merely focus on its promotion of individual responsibility (which justifies the dismantling of social protection) and on its tendency to reduce the status of citizen to that of a consumer who is financially solvent (such that financial insolvency results in a loss of citizenship). Described as such, however, the neoliberal subject is merely a liberal subject deprived of the safety net distinctive of the welfare state's embedded liberalism. (There are, of course, a number of authors, for the most part nourished by Foucault's approach to neoliberalism, whose work contradicts this self-serving claim: to name only a few, Wendy Brown, Barbara Cruikshank, Thomas Lemke, and Nikolas Rose.) 
First, the definition of human capital was broadened so that its evaluation would include a multiplicity of factors: some innate (e.g., one's genetic background and individual dispositions), others contextual (e.g., one's social milieu, one's parents' ambitions and care) as well as collateral (e.g., one's physical capital or psychological capital, ranging from one's diet or sports regimen to one's sex life or recreational activities). In short, the things that I inherit, the things that happen to me, and the things I do all contribute to the maintenance or the deterioration of my human capital. More radically put, my human capital is me, as a set of skills and capabilities that is modified by all that affects me and all that I effect. Accordingly, the return on human capital no longer manifests itself solely in calculations about whether to work or to receive more training. It now refers to all that is produced by the skill set that defines me. Such that everything I earn - be it salary, returns on investments, booty, or favors I may have incurred - can be understood as the return on the human capital that constitutes me.

Yet, as Schultz puts it, "not all investment in human capital is for future earnings alone. Some of it is for future well-being in forms that are not captured in the earnings stream of the individual in whom the investment is made."5 In other words, following Irving Fisher's distinctions and correlations among monetary, real, and psychic incomes, Schultz and Becker make it clear that returns on human capital cannot be understood as a mere influx of money. ${ }^{6}$ According to Becker, investments in human capital such as "schooling, a computer training course, expenditures in medical care, and lectures on the virtues of punctuality and honesty" are indeed likely to "raise earnings," but they can also "add to a person's appreciation of literature over much of his or her lifetime."7

While Becker and Schultz greatly expand the purview of the notion of human capital, in terms of both input (not only education but parental and social influences, lifestyle choices, etc.) and output (not only monetary earnings but satisfac-

5. Theodor W. Schultz, "Reflections on Investment in Man," Journal of Political Economy 70 (1962): 7.

6. According to Fisher, the income produced by a capital is its "service," which can be monetary, material, and/or psychic. For instance, the income or service of a house can be rent, shelter, and/or a sense of comfort. Fisher adds that psychic incomes ultimately subsume the monetary and material kinds, while monetary incomes ultimately measure the material and psychic kinds. See Irving Fisher, The Nature of Capital and Income (New York: Kelley, 1965), 106. Regarding Fisher's influence on the inventors of the concept of human capital — an influence widely recognized by neoliberal economists, including Schultz — see Annie L. Cot, "L'économie hors d'elle-même: Essai sur le néoutilitarisme" (PhD diss., Université de Paris I, Pantheon-Sorbonne, 1988), 123-87.

7. Gary S. Becker, Human Capital: A Theoretical and Empirical Analysis with Special Reference to Education, 3rd ed. (Chicago: University of Chicago Press, 1993), 15-16. 

remains that of traditional, that is, pre-neoliberal, utilitarianism. Indeed, in their view, investments in human capital should essentially be analyzed in terms of the returns they produce, that is, in terms of income. As they see it, the calculations of someone investing in his or her human capital are ultimately of the same order as those of a neoclassical consumer seeking to maximize his or her utility and of a company looking for long-term commercial profit. However, in the neoliberal world of globalized and unregulated financial markets, corporate governance is concerned less with optimizing returns on investment over time than with maximizing the distribution of dividends in the short run. Accordingly, its major preoccupation is capital growth or appreciation rather than income, stock value rather than commercial profit. ${ }^{8}$

Now, if we apply this major strategic shift in governance to human capital, it appears that an investor in his or her human capital is concerned less with maximizing the returns on his or her investments - whether monetary or psychic than with appreciating, that is, increasing the stock value of, the capital to which he or she is identified. In other words, insofar as our condition is that of human capital in a neoliberal environment, our main purpose is not so much to profit from our accumulated potential as to constantly value or appreciate ourselves - or at least prevent our own depreciation.

Such a change of purpose is ultimately what distinguishes the neoliberal condition from its liberal predecessor: while the utilitarian subjects still postulated by Becker and other rational choice theorists seek to maximize their satisfaction, and thus make their decisions accordingly, their neoliberal counterparts are primarily concerned with the impact of their conducts, and thus of the satisfaction they may draw from them, on the level of their self-appreciation or self-esteem. This strategic shift immediately raises the question of measurement: as Becker explains, the returns on investments in human capital can be measured in terms of monetary, real, and/or psychic income — from better wages to improved appreciation

8. It may seem unfairly harsh to accuse major economists of the Chicago school such as Becker and Schultz of not being neoliberal enough. In their defense, one should recall that they developed the concept of human capital in the 1960s, at a time when global, unregulated financial markets and their effect on corporate governance were hardly foreseeable. However, even in his most recent books - such as Social Economics: Market Behavior in a Social Environment (Cambridge, Mass.: Harvard University Press, 2000), coauthored with Kevin M. Murphy, in which he deals with the notion of social capital - Becker largely remains a neoliberal theorist trapped in a utilitarian imagination. Thus his relationship to the neoliberal condition may one day be described as that of G. W. F. Hegel to Marxism - or, for that matter, as that of Moses to the Promised Land. 
of literature. But how are we to measure self-appreciation? How can we account for an increase in the stock value of the human capital that we are? Of course, neoliberal policies and discourses eagerly answer this question: the "bankability" of an actor, the "employability" of a worker, and the "marketability" of a person's skill, talent, or invention are all meant to be partial estimates of the value of human capital. However, these alleged estimates should be seen as what they are, namely, relatively crude speculations insofar as they are based on income - after all, a bankable actor with low self-esteem is as common as a profitable company with a plummeting capital value.

As with any stock in a global and unregulated market - the conditions presiding over the appreciation and depreciation of human capital - the conditions under which neoliberal subjects come to appreciate themselves more or less are especially difficult to predict, both because the future marketability of a conduct or a sentiment cannot easily be anticipated and because the correlation between financial and psychological forms of self-appreciation cannot be homogeneously established.

In short, all one knows of human capital is the following: (1) the subjects that it defines seek to appreciate and to value themselves, such that their life may be thought of as a strategy aimed at self-appreciation; (2) all of their behaviors and all the events affecting them (in any existential register) are liable to cause the subjects either to appreciate or to depreciate themselves; and (3) it is therefore possible to govern subjects seeking to increase the value of their human capital, or, more precisely, to act on the way they govern themselves, by inciting them to adopt conducts deemed valorizing and to follow models for self-valuation that modify their priorities and inflect their strategic choices.

Regarding this last point, it is worth noticing that when Foucault studied human capital in his 1979 lectures on neoliberalism, he related neoliberal policies to Skinnerian psychology, the precursor to today's cognitive-behavioral therapy, where the aim is to modify the patient's behavior, to make it more efficient and less dysfunctional by modifying his or her environment. ${ }^{9}$ While this correlation is well suited to the neo-utilitarian approach to human capital - that is, to strategies that aim at maximizing the returns on investments in human capital - it is arguably the psychological discourse of "self-esteem" that is the most accurate

9. Michel Foucault, Naissance de la biopolitique: Cours au Collège de France, 1978-1979 (The Birth of Biopolitics: Lectures at the Collège de France, 1978-1979) (Paris: Gallimard/Seuil, 2004), $273-74$. 

of human capital. ${ }^{10}$

Let us consider for a moment the differences between human capital and the free laborer. The free laborer, we have seen, is a split being. He or she is split between a subjectivity that is inalienable and a labor power that is to be rented out; he or she is split between the reproduction of a society of free laborers (i.e., its biological, social, cultural, and moral reproduction) and the production, circulation, and consumption of commodities. Last, he or she is split between spiritual aspirations and the pursuit of material interests: the former are necessarily specific to the individual and are thus incommensurable, while the latter are universal, or at least commensurable, and thus lend themselves to possible modeling and calculations. And while individuals' spiritual aspirations exist in a realm of desires that are not negotiable and of gifts that are fully disinterested, individuals' material interests are always the object of exchange and negotiations and are understood only in terms of benefit and cost. As a result of these divides, there is necessarily a difference between the principles and values that exist in the marketplace and those one finds outside the marketplace. Indeed, for free laborers to think of their labor power as a commodity, they must be certain that they are not themselves commodities, which is to say that some aspects and regions of themselves remain inalienable, lest they end up entirely robbed of their selves. ${ }^{11}$

10. As a major cultural phenomenon, preoccupation with self-esteem peaked in the 1980 s and 1990s, which partly explains why Foucault did not take it into account. However, the connection between self-esteem and neoliberalism can be traced back to the late 1960s. Indeed, one of the first popular and influential books on self-esteem was Nathaniel Branden, The Psychology of Self-Esteem: A New Concept of Man's Nature (Los Angeles: Nash, 1969). At the time, Branden was known as the former lover and protégé of Ayn Rand as well as a coauthor of Capitalism: The Unknown Ideal, a book written with Rand, Robert Hessen, and . . . Alan Greenspan. About twenty years later John Vasconcellos, the California lawmaker responsible for the creation of the California Task Force to Promote Self-Esteem and Personal and Social Responsibility, proved worthy of Branden's pioneering work when he stressed the task force's economic importance by claiming that "people with selfesteem produce income and pay taxes, [while] those without tend to be users of taxes" (quoted in Roy Baumeister, ed., Self-Esteem: The Puzzle of Low Self-Regard [New York: Plenum, 1993], viii). Regarding the California Task Force on self-esteem as exemplary of neoliberal governmentality, see Barbara Cruikshank's compelling essay "Revolutions Within: Self-Government and Self-Esteem," in The Will to Empower: Democratic Citizens and Other Subjects (Ithaca, N.Y.: Cornell University Press, 1999), 87-103.

11. Debates about prostitution are typically predicated on this distinction: while advocates of the abolition of prostitution understand sexuality to be part of what a subject is, of what makes a human 
Public Culture

real subsumption of subjectivity?

Human capital, by contrast, does not presuppose a separation of the spheres of production and reproduction. The various things I do, in any existential domain (dietary, erotic, religious, etc.), all contribute to either appreciating or depreciating the human capital that is me, no less than does my diligence as a worker or my ability to trade my professional skills. As investors in their own human capital, the subjects that are presupposed and targeted by neoliberalism can thus be conceived as the managers of a portfolio of conducts pertaining to all the aspects of their lives. Accordingly, state policies and corporate strategies aimed at governing neoliberal subjects - that is, at setting the conditions of appreciation of their human capital - expose them to measures intended to influence the rate of each stock in their portfolio with little regard for venerable oppositions such as productive versus reproductive activities (production of commodities versus reproduction of the labor force), public versus private, or professional versus domestic.

That said, claiming that human capital, as an emerging subjective formation, erodes the distinction between production and reproduction is not the same as agreeing with the most common criticism of neoliberalism, which is that it commodifies everything and gradually subjects the entire planet and all of human existence (i.e., all of time and space) to the laws of the market. This critique, the hallmark of the detractors of neoliberal globalization, likens the neoliberal condition to that of a free laborer besieged by an ever-expanding market and thus reduced to a mere consumer where once he or she also was a citizen (or a flaneur, a user of public goods, an art aficionado, a lover, etc.). From this characterization stems a humanist protest, which often amounts to the expression of a longing for the free laborer of yore: the world is not a commodity, the argument goes; what I am cannot be reduced to what I can buy; my desires cannot be reduced to the laws of supply and demand; there can be no humanity in a world where everything is for sale...

Yet - and this is something on which Foucault insists - if we take seriously the subjective apparatus of human capital, we can see that neoliberalism in fact treats people not as consumers but as producers, as entrepreneurs of themselves or, more precisely, as investors in themselves, as human capital that wishes to

being a subject, rather than something that can be owned and traded in the marketplace, supporters of the regulation of prostitution claim that a free subject owns his or her body and is thus entitled to rent out, as labor power, whatever bodily service that he or she chooses. Though the two camps disagree on what constitutes "alienation," both their positions pertain to C. B. McPherson's definition of the liberal condition, namely, "possessive individualism." (A neoliberal take on prostitution, by contrast, would consider prostitution in terms of how selling sexual favors affects the self-appreciation of the human capital engaged in such activity.) 
appreciate and to value itself and thus allocate its skills accordingly. ${ }^{12}$ This has implications for our understanding of what kind of opposition or resistance neoliberalism can produce: from the perspective of the commodification critique, resisting neoliberalism means refusing the expansion of the market and insisting that a genuine subject cannot be reduced to a mere consumer, that the free laborer has aspirations that cannot be reduced to calculations of interest (a longing for solidarity, justice, or sharing). From the standpoint of the "capitalization" of oneself, however, the conflict - or, at any rate, the conflict that would give rise to a Left that is not liberal but neoliberal (or, more precisely, to a Left that is adequate to neoliberalism) - is rather a contest between different ways of appreciating and of valuing oneself, a competition over the conditions and modalities of the valorizing of human capital, over what behaviors deserve to be included in my portfolio because they allow me to appreciate and to value myself.

The implications of the erosion of the boundary between the spheres of production and reproduction (an erosion that follows from the replacement of the free laborer by human capital as the target and basis of neoliberal policies) can also be understood from another angle. Thus, for instance, when Foucault embarks on his study of "neoliberalisms" - German neoliberalism, first, and then American neoliberalism — he begins with the following idea: on the one hand, liberalism originally claimed to be consistent with man's natural rationality. If governments must not govern too much, argued the early liberals, it is because the rational calculations that people spontaneously carry out to maximize their profit or their personal utility are also the best engines of collective welfare: the pursuit of private interest leads to public prosperity. Liberalism, in other words, wanted to protect the spontaneous utilitarianism of individuals against governmental constraints, and this protection was justified in the name of both freedom and efficiency: people's spontaneous calculations, if unhampered, create a market, which in turn maximizes the wealth of all those calculating. But, on the other hand, as Foucault also explains, liberals quickly learned that the invisible hand of the market is a fragile organ that must be adjusted constantly; most of all, they realized

12. Even consumers as such should be perceived as producers. According to Becker, and contrary to the fears expressed by Daniel Bell in The Cultural Contradictions of Capitalism, the subjects of mass consumption are not these complacent and infinitely demanding human beings who threaten the enterprising and ascetic spirit of capitalism. Instead, they should be perceived as the producers of their own satisfaction: indeed, the latter is defined as a set of commodities "produced by the consumer unit itself through the productive activity of combining purchased market goods and services with some of the household's own time." See Gary S. Becker, The Economic Approach to Human Behavior (Chicago: University of Chicago Press, 1976), 134. 
that individuals need specific conditions (which their calculations alone cannot create) to behave "naturally" as profit-seeking rational calculators.

Liberal governmentality, hence, has consisted in restricting the activity of calculating individuals to the sole sphere of commodity production/circulation/ consumption, and in "surrounding" the latter both with regulatory measures intended to compensate for markets' tendency to malfunction (e.g., antitrust legislation) and with disciplines designed to shape and reproduce individuals who can and want to use their natural rationality. The deployment of liberalism is thus inseparable from a distinction between the sphere of production and the sphere of reproduction, where the latter serves to (re)generate individuals who seek to optimize the market value of what they own - and does this by subjecting them to norms, inculcating them with values, and providing them with services that do not obey the rules of commodity exchange and production. The sphere of reproduction is one that values selfless giving (whether in one's relation to God or to one's neighbor), exalts people's unconditional ties (with their family, with their nation, and with humanity), and justifies the social services required for the physical and psychological upkeep of individuals, to prepare them for their entry into the market, or to ensure that they will be able to maximize their usefulness when they are not (or no longer) employable.

According to Foucault, the "constructivist," or constructionist, character of liberalism (i.e., the fact that individuals must be carefully prepared in order to display their natural rationality and thus make good use of their freedom) will become more and more explicit: the endpoint of this evolution - but it is also a turning point — can be tied to the "social market economy" developed by German Ordoliberals in the 1940 s and 1950 s. ${ }^{13}$ Breaking with the idea of liberalism as laissez-faire, Ordoliberals advocated and applied a "politics of society" (Gesellschaftspolitik), which they thought could be as interventionist as a Keynesian or a socialist dirigiste policy but which was aimed at arranging and protecting the proper functioning of this fragile thing that is the market, by giving people the means and the desire to behave as competing entrepreneurs. This marked a reversal of liberalism's original core - a first neoliberalism, in a sense - insofar as market competition was conceived no longer as a gift of nature to be preserved but as a social form to be produced and reproduced, because it is optimal without being given.

13. Ordoliberalism — named after the journal Ordo, founded in 1948 — refers to a group of scholars, such as the economists Walter Eucken and Alfred Müller-Armack and the legal scholar Frantz Böhm, whose doctrine shaped the economic policies of the German Federal Republic after World War II. See Foucault's analysis of their perspective in Naissance de la biopolitique, 77-191. 
American neoliberals, such as the leading members of the Chicago school of economics, endorsed this notion of a society of entrepreneurs that must be produced and maintained, but at the same time they began worrying over the cost of this production: indeed, the social market economy (soziale Marktwirtschaft) can succeed in producing a society of competing entrepreneurs only if there is the maintenance (and possibly the growth) of a large nonmarket sector - the sphere of reproduction. American neoliberals thus devoted themselves to challenging the confinement of the market to the sphere of production and thus to allowing market relations to conquer the space of the politics of society, which Ordoliberal economists had understood as necessary for the (re)production of the market but as obeying a different rationality. In other words, what was at stake for Schultz, Becker, and their associates was to challenge the alleged heterogeneity between the aspirations of the authentic self and the kind of optimizing calculations required by the business world (a heterogeneity that, until then, liberalism had understood as indispensable to the proper functioning of the business world).

It is precisely as a consequence of this desire to overcome the divide between the intimate man and the entrepreneur that one should understand the promotion of human capital - that is, the presentation of the individual as "investor in himself or herself." Indeed, thanks to this change of subjective frame, domains such as health, education, culture, and the like are no longer conceived as "external" conditions necessary for the reproduction of the entrepreneur / free laborer: they instead become sectors of the valorizing of the self (understood as capital). At the same time, the promoters of human capital share the German Ordoliberals' conviction that the construction of a neoliberal society requires means other than laissez-faire: in other words, they do not believe that the proper criteria and modalities for the appreciation of the self, the ways of allocating one's competences and the ideals governing such allocations, are simply natural dispositions that ought to be preserved from governmental interventions. On the contrary, the neoliberal art of government is precisely about playing the human capital market, about betting for or against certain behaviors, sentiments, and lifestyles to shape the portfolios of conducts that the governed are taken to be.

As Foucault repeatedly recalls in Naissance de la biopolitique, American neoliberalism developed in reaction to what its initiators saw as the rampant socialism of the welfare state (in its Keynesian and social democratic versions) and even of the Ordoliberal version of the market social economy. According to neoliberal economists of the Chicago school - as well as their colleagues belonging to the Austrian branch of neoclassical thought, such as Friedrich Hayek and the libertarian economists Ludwig von Mises and Murray Rothbard - the growth of the 
nonmarket sphere, even if conceived, as the Ordoliberals would have it, as the basis for a society of competing entrepreneurs, is a mistake and a threat to be averted. Redefining the social subject as human capital (and defining human capital as a subject wishing to appreciate himself or herself), therefore, does serve the function of regaining the territory that the welfare state increasingly surrenders to the nonmarket sector in the name of reproducing an eager and functional free laborer.

However, in the process of this effort to roll back state control and redistribution, neoliberals have largely done away with the liberal condition once hailed by Adam Smith and later denounced by Marx. Indeed, contrary to the relationship of liberal entrepreneurs to their businesses and that of free laborers to their labor power, the relationship of a neoliberal subject to his or her human capital cannot be properly defined as ownership and thus escapes the liberal realm of possessive individualism. In other words, while labor power is the property of the free laborer, neoliberal subjects do not exactly own their human capital; they invest in it. In fact, anything they do, no matter how ill advised or mundane, is an investment in their human capital, since the latter is the portfolio composed by their behaviors - and they benefit from it - insofar as they receive the dividends of the conducts that their portfolio includes. But while they can considerably alter their human capital - by means of either diversifying or modifying their behaviors and social interactions - they can never sell it. In short, rather than a possessive relationship, as that of the free laborer with his or her labor power, the relationship between the neoliberal subject and his or her human capital should be called speculative, in every sense of the word.

At the very time when neoliberal economists were honing their approach at the beginning of the 1960s, the welfare state in its various guises also became the target of a radical Left critique. According to the latter, the trouble with investing in the conditions of reproduction of the free laborer was not that it called for the indefinite growth of the nonmarket sphere but that it simultaneously dampened the revolutionary fervor of the working class in the West and caused revolutions to lapse into bureaucracy in the so-called socialist world. Indeed, what the promoters of a "New Left," such as Herbert Marcuse and Guy Debord, saw as the major threat to socialist emancipation in the age of mass consumption involved the constant development of public and/or private investments aimed at ensuring that human beings continued to perceive themselves as subjects of interests and 
thus to delegate the management of their lives to those institutions claiming to represent their interests.

Throughout the 1960s and 1970s, and despite the considerable differences among them, the various branches of radical leftist thought - whether informed by psychoanalysis, Friedrich Nietzsche, or Marx's Grundrisse - shared the conviction that the struggle against capitalist exploitation would continue to be either derailed by consumerist stupor or perverted by bureaucratic control, unless the liberal condition to which both welfare capitalism and authoritarian socialism are correlated was theoretically deconstructed and practically undone. The ensuing critique dealt with the distinction and the articulation of the three constitutive tenets of liberal subjectivity: (1) an insatiable desire chiefly expressed through pride, lust, and greed; (2) various forms of disinterested love — charity, motherly love, benevolence, compassion - alternatively meant to soothe and to humble the desirous nature of the subject; and (3) a utilitarian sense of self-interest, designed to optimize through free and contractual exchanges the satisfaction of the desires that disinterested love can neither satiate nor suppress. The combination of these three tenets defines a human condition that is subjected to incessant desires, either as a punishment for an original sin or as an effect of natural scarcity; that is dependent on unconditional love, given by God, social institutions, and/or fellow human beings; and that is endowed with a capacity to negotiate its interests and thus to manage some of its urges without violence, even in the absence of love. To some extent, it is true that the critique of this liberal condition can be found in, or at least extracted from, Marx's assessment of the free laborer as the correlate of liberal capitalism. Yet the fact remains that the labor movement did appropriate this subjective form. On the one hand, its representatives relied on liberalism's humanist claims, that is, on the crucial role given to disinterested feelings in the reproduction of free and dignified liberal subjects, to limit the expansion of market relations. On the other hand, they also endorsed the notion of interest, if only to attach it to social classes, rather than individuals, in order to raise the exchange value of labor power.

This dual strategy was precisely what the various movements among the radical Left in the 1960s and 1970s sought to contest. In their view, appropriating the condition of the free laborer had become more damaging than beneficial, insofar as it could contain capitalist exploitation only at the cost of consolidating the very type of subject (or, more precisely, the type of subjection) on which capitalism is predicated. Consequently, the liberal condition was submitted to a threefold critique: 
First, the association of desire and want, the construction of desire as a symptom of a lack that can never be overcome, was denounced as a way of inscribing in the human condition the need for a savior or, at any rate, a certain call for transcendence. (The most famous and forceful political critique of the correlation between desire and a longing for transcendence inherent in human subjectivity was that of Gilles Deleuze and Félix Guattari in Anti-Oedipus.) ${ }^{14}$

Second, the exaltation of disinterested love and benevolence - as the first countervailing affect meant to curb the violence of desire - was described not as a praise of generosity, let alone an invitation to share and cooperate, but as the deployment of a mode of government whereby the recipients of solicitude are made to recognize their infinite indebtedness and dependence vis-à-vis their benefactors - and to behave accordingly. (This decidedly Nietzschean perspective informed Foucault's analysis of Christian pastoral power and of its secular avatars. $)^{15}$

Third, the moral validation of the propensity to pursue one's economic interests - deemed the second countervailing affect capable of curbing the violence of passionate desires - was accused not only of justifying capitalist exploitation but also of inciting self-interested subjects to conform to the requirements of those institutions purported to optimize the pursuit of their interests, for instance, the market in liberal societies and the Communist Party under state socialism. (Distinctive of the workers revolts in Western Europe in the late 1960s and early 1970s, where the object of social struggles involved the very condition of the free laborer rather than the exchange value of labor power, the radical critique of the subject of interest as the correlate of capitalist and socialist subjection was also the critical hallmark of Italian operaismo. $)^{16}$

Though this threefold critique was hardly homogeneous, its various proponents did not merely agree on the importance of analyzing subjective formations as correlates of modes of government rather than as "super-structural" effects or reflections of a mode of production and distribution of wealth. Having stressed that the liberal condition was operative under state socialism as well as under welfare

14. Gilles Deleuze and Félix Guattari, Anti-Oedipus: Capitalism and Schizophrenia, trans. Robert Hurley, Mark Seem, and Helen R. Lane (New York: Viking, 1977).

15. See in particular Michel Foucault, Sécurité, territoire, population: Cours au Collège de France, 1977-1978 (Security, Territory, Population: Lectures at the Collège de France, 1977-1978) (Paris: Gallimard/Seuil, 2004).

16. See in particular Mario Tronti, Operai e capitale (Workers and Capital) (Turin: Einaudi, 1977); and Antonio Negri, Marx oltre Marx: Quaderno di lavoro sui "Grundrisse" (Marx beyond Marx: Lessons on the "Grundrisse") (Milan: Feltrinelli, 1979). 
capitalism, they all insisted on its paradoxical nature. Indeed, while ostensibly free, liberal subjects must eventually recognize their heteronomy: their desires are the symptom of a fundamental lack, the love they crave reveals their dependence and indebtedness, and the pursuit of their interests leads them to conform to rigid and homogenizing norms.

Based on this assessment of the liberal condition, its radical critics conceived their own political agenda as a quest for autonomy. Their concern was not to abolish the empire of (self-)interest through the liberation of desire or the celebration of "pure" love, however, but to expose the subjection inherent in the liberal articulation of these three categories. In other words, the purpose of their critique was to question the norms according to which individuals subjected to the liberal condition are pressed to govern themselves, in order to enable them to gain the agency or autonomy required to conduct and appreciate their lives differently.

Neoliberal and "radical" critiques of the liberal condition clearly came from opposite political corners and harbored antagonistic aspirations. At the same time, however, they not only developed during the same period, and out of an equally acute allergy to the hegemony of the Keynesian welfare state, but also centered their critical perspective on the subjective formation that liberal governmentality presupposes, targets, and seeks to reproduce. Indeed, for both neoliberal and radical critics of the 1960s and 1970s, the relationship that individuals establish with themselves - how they care about and take care of themselves - emerged as the privileged framework for political reflection.

This does not mean that either group has neglected social relations or, to put it differently, that neoliberals and leftist radicals resemble one another in that they represent the two sides of the same postmodern narcissistic coin. Though popular among eulogists of the liberal condition — on the left as well as on the right — the conflation of neoliberal self-appreciation and radical autonomy under the rubric "selfishness" is misguided. What neoliberal and radical critics of the liberal condition have in common is not that they give precedence to self-regard over the regard for others but that they consider the regard for others from the perspective and as a constitutive part of self-regard. Far from disregarding social concerns to merely focus on personal ones, they no longer recognize the pertinence of allocating the care of others and the care of the self to two distinct realms. In a way, they both hold on to the notion that "the personal is (the) political" - that the contest for the definition of the conditions under which we may appreciate ourselves is politically decisive. 
While neoliberal and radical critiques were both instrumental in breaking down the constitutive oppositions of the liberal condition - production versus reproduction, domestic versus public, personal versus political, and so on - in the past three decades, only the former has imposed its definition of what selfappreciation entails: for its part, the latter has been largely repudiated both by a "modern" Left in desperate search of an appealing light version of neoliberalism and by an "authentic" Left patiently waiting for its putative constituents to wake up and understand where their real interests are. By contrast, challenging the neoliberal condition from within, that is, embracing the idea that we are all investors in our human capital, in order to contest the alleged conditions under which we appreciate ourselves, would amount to rejoining the radical sensibility of the 1960s and 1970s. Instead of denouncing and lamenting the personalization of politics as the strategy through which neoliberalism causes people to lose sight of their collective interests, playing the human capital card could thus be a way of relaunching the politicization of the personal.

What remains to be examined are the practical implications of embracing the neoliberal condition from the left. Is this simply a matter of rhetorically recasting a time-honored progressive agenda, of recycling it and couching it in terms of self-appreciation? In other words, is it just a question of developing a discourse where one's sense of self-worth would depend on one's commitments to matters such as a progressive and redistributive system of taxation, the defense of public services, or support for civil liberties and open borders? Such an exercise might in fact have its merits, if only to help extirpate the Left from its current melancholy.

One can also hope, however, that challenging neoliberalism on its own turf opens up possibilities that go beyond merely translating traditional progressive not to say liberal - demands into the idiom of New Age psychology. Indeed, a number of new social movements are already making use of the attributes of the neoliberal condition to challenge the neoliberal policies.

Consider, first, the resistance that was generated by "workfare" programs, such as those advocated by the proponents of the "Third Way" in Great Britain and in the United States, and that lay at the heart of Bill Clinton's welfare reform (whose watchword was to "help people help themselves"). The template of neoliberal governance, these programs are meant to cut unemployment benefits - limits are placed on how long one could receive them - as well as to make them strictly conditional on one's actively looking for a job and being ready to accept any job offer. Their goal is allegedly to reduce public spending, but it is also, and even 
chiefly, if we are to believe workfare promoters, to encourage people to choose and prefer work over welfare: not only do they have little choice, but - so the argument goes - work reinforces autonomy and leads the individual to value himself or herself more. In addition, workfare programs tend to include positive incentives to see oneself as a job seeker rather than as a welfare recipient: individuals must have access to training programs during periods of unemployment to increase their employability and thus ward off the depreciation of their human capital.

While exponents of the "authentic" Left denounced workfare programs as the final betrayal of the welfare state, and while representatives of the "modern" Left sheepishly endorsed them as an unavoidable evolution, Scandinavian labor unions endeavored to work through them. Taking stock of the fact that, in a globalized and post-Fordist environment, ensuring job security can no longer be the aim of labor unions, the promoters of Danish "flexsecurity" and of its Swedish equivalent have sought instead to make the professional trajectory of workers more secure, that is, to help them navigate the changes that affect their professional life (periods of unemployment, moving from one place or sector to another, etc.) without losing their means of subsistence and, perhaps most important, without losing their employability (indeed, turning these episodes into possible occasions for increasing the value of their human capital). This new orientation of the work of labor unions is, of course, particularly adapted to Scandinavian countries, where by virtue of their tradition and high membership rates, labor unions will tend to think of themselves as providers of personal services (training, help in finding a job, etc.) rather than as merely defenders of class interests.

For all practical purposes, Scandinavian unions have merely softened the effects of workfare programs rather than modified their orientation. Yet how they approached the issue raises, at least potentially, the question of the content that will be given to what French labor unions call "professional social security," namely, the management of a worker's trajectory. Indeed, the potential conflicts over what a person needs to navigate a flexible labor market are not simply conflicts over what type of protections will be guaranteed or over how these protections will be financed. Rather, they are over the more profound questions of what constitutes the basic conditions, the criteria, and the required means for self-appreciation. Clinton's slogan, in other words, has become an open question: What does it really mean to help people help themselves? What does one need to appreciate and to value oneself? The problem has quantitative aspects (e.g., what should be the size and distribution of investments in human capital, how does one measure the training received, and how can training be incorporated into salary?) 
as well as qualitative aspects (e.g., what types of training and what types of incentives or aid for job seekers encourage self-appreciation?). These aspects will have to be addressed, and they delineate a space of confrontation in which it may be possible for a Left discourse about autonomy to reconstitute itself.

Moreover, the concern over self-appreciation — or, more precisely, the recognition of the legitimacy of this concern - also informs an emerging set of challenges to private property and its prerogatives. Indeed, while the outcome of the Cold War and the declining influence of labor organizations have robbed the critique of capitalist exploitation from much of its galvanizing power, the contention that the moral and juridical hegemony of property rights can be an obstacle to a person's legitimate concern for the quality and value of his or her life has made considerable headway.

On the one hand, this contention largely informs the conflicts raised by the question of access - access to health, to knowledge, to culture - and its modalities: in other words, it informs the various conflicts about intellectual property. It is probably the case that, in the multiple disputes between the upholders of property rights and the promoters of users' access (whether to the products created or to the creative process itself), the latter are likely to invoke different principles according to their specific area of activism. For instance, supporters of generic drugs - especially with regard to AIDS and other illnesses primarily affecting the global South - tend to promote their cause by speaking the language of need and referring to the fight against poverty. Meanwhile, activists involved in making knowledge more accessible in developing countries are inclined to speak in terms of economic development and to liken knowledge to public services and goods. As for advocates of open networks and free software, they usually invoke individual freedom and stress the economic cost of repressing it. However, insofar as these diverse movements attempt to form an alliance, they are pressed to find a common frame of reference. Since they can neither rely on class interest nor easily attach their claims to fundamental rights (which would tend to favor intellectual property), their propensity is to appeal to the legitimacy of the aspiration to appreciate or to value oneself - or, more precisely, to the legitimate desire to have access to the resources required for meeting the physical and cultural conditions for self-appreciation. The latter thus becomes the political common ground shared by those various activists advocating access, as well as their main justification for circumventing the common law of intellectual property.

On the other hand, it is also the legitimacy of their desire to increase the value of their existence (or to prevent its depreciation) that brings together various stakeholders in a corporation (i.e., not only the workers, consumers, and sup- 
pliers, who all contribute to the commercial activity of the company, but also its neighbors, or even the public at large, whose environment is affected by this activity). Such a desire is ultimately what puts their demands in competition, if not on a par, with the prerogatives of the company's shareholders. More than the fact that a company's owners unduly appropriate the product of the labor process and thus exploit their workers, what is now likely to be held against these owners is that they violate the conditions required for the lives of the stakeholders to be valued or to appreciate (the quality of what they consume, the cleanliness of their environment, respect for their work, etc.). And there, too, it is not so much in the name of a common interest or of a recognized right that the stakeholders are challenging the shareholders' power, as in the name of their common desire to make their lives valuable. ${ }^{17}$

In terms of discursive strategy, neoliberalism can boast two major successes: its promoters have made it legitimate to want to care for oneself while presenting themselves as the champions of personal responsibility (insofar as their policies identify self-appreciation with self-reliance). Their leftist opponents, by contrast, are accused of making people feel unduly guilty (by implying that the desire to value oneself is mere egoism) and, at the same time, of fostering complacency and irresponsibility (by allowing people to rely on social benefits rather than on personal effort and by making self-appreciating citizens pay for those who have squandered their human capital). Thus it may be that for the Left, challenging neoliberal modes of self-appreciation, rather than rejecting the framework of the neoliberal condition, is not only a sound tactical move. More decisively, it may also be a way of warding off its current melancholy by means of reentering the domain of the enviable and desirable — of raising, from its own perspective, the question of what constitutes an appreciable life.

Translated from the French by Ivan Ascher

17. Neoliberal governmentality, so far, has recognized and addressed this concern more readily than has its leftist opposition, and it has responded to it by inviting stakeholders to go "to the other side" - that is, to treat the acquisition of property as the preferred path toward self-appreciation. Such a strategy has obviously been very successful, at least until the recent real estate crisis, since when stakeholders behave as future owners or shareholders, they end up working against the conditions of their current well-being - all the more so if they hope to quickly join the ranks of the propertied. 
